\title{
The Dominant Types of Holiday Developments near Warsaw around 1900 with Reference to the Main Social Groups and Their Preferred Forms of Leisure
}

\author{
Agnieszka Bąk
}

Tutor: prof. nzw. dr inż. arch. Małgorzata Rozbicka; Faculty of Architecture, Warsaw University of Technology, Poland

E-mail address: agnieszkabak7@gmail.com

\begin{abstract}
The summer resorts near Warsaw developed at the turn of the 19th and 20 th centuries had varying characters, resulting mainly from the differing social and material status of their vacationers. Based on the research of leisure facilities from this period located in 31 towns and villages within a radius of $50 \mathrm{~km}$ of Warsaw, the dominant types of holiday developments have been identified (including functional and spatial solutions, elements of architectural styles and relationship with nature), with reference to the main social groups of Warsaw around 1900 and their preferred forms of leisure.
\end{abstract}

KEYWORDS: Summer resort; leisure architecture; summer villa; summer apartment; guest house; pension

\section{Introduction}

The development of holiday villages near Warsaw was brought about by economic, social and cultural changes in the city in the second half of the 19th century. Progressing industrialization resulted in a rapidly growing number of residents. In 1874, $261249^{1}$ people lived in Warsaw, by 1897 - 624 189. In less than 25 years, the population nearly tripled $^{2}$. The city grew within the strict limits set by the forts of the Warsaw Fortress, 
which resulted in intensified urban development and considerable population density. Life in the capital city was associated with numerous inconveniences, including damp apartments with insufficient ventilation, in which too many people lived in one room, polluted air, narrow streets, high houses and dense urban development, lack of greenery and natural airflow, often dire hygiene and health conditions. Hence, among representatives of all social strata, there was a desire to travel to the country to experience nature. The trend for leisure trips in the second half of the 19th century was facilitated by the development of convenient rail connections, initially long-distance lines, followed by suburban ones.

\section{Social strata}

The time, places and forms of leisure of Warsaw residents in the 19th century depended on their means. Marek Olkuśnik divided Warsaw society into social strata, taking into account their financial resources and the free time they could devote to leisure ${ }^{3}$. The wealthiest strata included aristocrats and landowners, well-situated professionals and entrepreneurs. They were financially independent and had a lot of free time. The middle class ranged widely. It included better-off employees, public servants, and the wealthier intelligentsia. The poor segment had limited financial resources, was strictly connected with work and did not have free time apart from public holidays. It included lower-level public servants, office workers, people employed in trade - the vast majority of Warsaw residents. The poorest group included uneducated people, often without a stable source of income - laborers and servants.

\section{Forms of leisure}

It is possible to recreate leisure activities of different social groups based on literature ${ }^{4}$. For the wealthiest of them, a summer vacation near Warsaw took place in addition to a spa trip taken abroad or a stay in a Polish health resort by the sea or in the mountains. In most cases they chose to stay in their summer residences. The middle segment, who had to take time and financial constraints into account, and aspired to a higher social position, usually went to spas or summer resorts located near Warsaw. Among this group, the most popular solution was the so-called "wilegiatura" - renting apartments or entire houses in the villages close to the major city in the summer season. Usually, women and children spent the whole summer there, while men worked in the city and commuted to Warsaw every day, or came to the summer resort on Sundays. Representatives of this group also built their own summer houses, less impressive than the summer residences of the most affluent group, or stayed at guest houses. The poor group rented more modest apartments or rooms. Families separated for the summer. Women with children stayed in summer resorts, and the men worked in Warsaw. In the case of the poorest segment, the dominant form of rest were walks in city 
parks or one-day trips on public holidays due to insufficient finances and lack of free time.

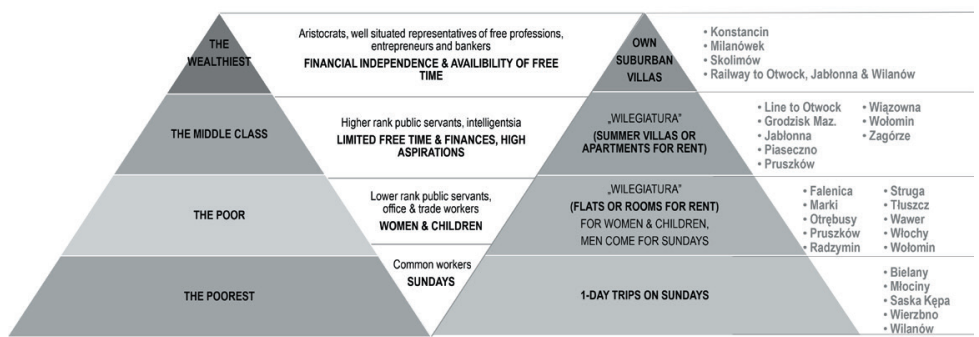

Img. 1. Social strata, forms and directions of leisure (Source: own development)

\section{Study}

Summer resort architecture near Warsaw experienced accelerated development at the turn of the 19th and 20th centuries - the study covered 173 buildings constructed in 31 towns and villages near Warsaw in the period between 1845-1914. The territorial scope of the research is a distance of approx. $50 \mathrm{~km}$ from the borders of Warsaw, accessible via available means of transport (mainly by rail) within an hour. Most buildings have been preserved in Otwock, Konstancin and Milanówek. For this research, 4 types of buildings were distinguished: summer residences of the owners, summer villas for rent (rented to one family), villas with flats and rooms for rent (rented to several families at the same time) and guest houses with full service, including meals.

\section{Examples}

An example of a summer residence for the wealthiest social group are the villas in Turczynek (designed by D. Lande), which served as summer residences for two related families and were "located $100 \mathrm{~m}$ away from each other, surrounded on three sides by a forest, the fourth side facing the park". In both, the functional layout was similar: "On the ground floor living room, cabinet, dining room, boudoir - reception rooms. Other rooms, i.e. bedrooms, children's rooms, rooms for teaching staff, guest rooms, bathrooms, toilets were on the first floor. Also, there were several guest rooms in the attic. In the basement there was a kitchen, laundry, mangle, service rooms, pantries, central heating" 5 . Representative rooms in an enfilade arrangement were typical for this type of facility. Picturesque, richly decorated and eclectic architecture was also typical. They were brick buildings with wooden details, designed by professional, often very good, architects ${ }^{6}$. Currently, villas in Turczynek are neglected and in disrepair. 
An example of a guest house for the middle classes is the Górewicz health resort in Otwock. The facility was a luxury spa. It was situated in a carefully designed and wellkept forest park. The venue was created in 1906 and was gradually expanded. The facility for 80 people consisted of seven wings and was open all year. It included, among others, a reading room, living room, a concert hall with a piano, a dining room, game rooms and halls. Wood was the basic construction and finishing material. It was one of the most impressive buildings in the so-called "świdermajer" style, typical of the architecture of many summer resorts near Warsaw. The woodcarving decorations on the veranda were ornamental and varied, designed separately for each wing. The layout of rooms in different parts of the building was 2- or 3-way. Rooms for patients were spacious, sunny, with Venetian windows overlooking the park. Currently, the facility is under revitalization.

An example of a summer villa with apartments for rent for the middle class is $\mathrm{R}$. Hagmajer's villa in Milanówek (designed by Ap. Nieniewski). In the villa, there were apartments with 2 or 3 rooms with kitchens and a veranda with a separate exit to the garden (on the ground floor) or to a balcony (on the first floor). Typical elements were modest woodcarving decorations on the façades, verandas, porches, projections, balconies and towers. Villas of this type were usually situated on small land plots in a forest environment, not far from the railway stations. The villa was not preserved.

Typical facilities for the poor were summer houses with small apartments or rooms for rent. Their designs were not published in magazines, and not many of them have been preserved. An example of a functional layout is a corridor with apartments that had shared entrance porches and separate exits to the garden through verandas, the premises on the first floor were accessible from the common corridor. The apartments consisted of 1-2 rooms and a kitchen, with toilets in the yard. Typical elements included verandas, porches, projections, modest woodcarving decorations and façade formwork.

\section{Conclusions}

The study covered 173 objects, but there were many more - over a thousand only in Konstancin, Milanówek and Otwock ${ }^{8}$, which means that their preserved examples are the "tip of the iceberg". The vast majority were wooden buildings, with few of them still existing today, which is why further action to document and protect them is so important. 


\section{Notes and resources}

1 Żurawicka, Joanna, 1978, Inteligencja warszawska w końcu XIX wieku. Warszawa: PWN.

2 Szulc, Stefan, 1920, Wartość materiałów statystycznych dotyczących stanu ludności b. Królestwa Kongresowego. Warszawa: GUS.

3 Olkuśnik, Marek, 2015, Wyjechać z miasta. Mieszkańcy Warszawy wobec podróży, turystyki i wypoczynku na przełomie XIX i XX wieku. Warszawa: Meriton.

4 Singer, Bernard, 1993, Moje Nalewki. Warszawa: Czytelnik; Fryze, Feliks, Chodorowicz, Ignacy, 1873, Przewodnik po Warszawie i jej okolicach, Warszawa; Kasprzycki, Jerzy, Majewski, Jerzy, 2004, Korzenie miasta, tom VI, Niedaleko od Warszawy. Warszawa: VEDA; Świątek, Tadeusz Władysław, 1995, Konstancin. Wędrówka śladami ludzi i zabytków, Warszawa: PTTK „Kraj”.

5 Przegląd Techniczny, 1905, No 45.

6 Przegląd Techniczny, 1905, No 52.

7 Przegląd Techniczny, 1908, No 43.

8 Herz, Lechosław, 2017, Pod odżywczym drzew cieniem...Na podwarszawskim Mazowszu, Warszawa: ISKRY.; Żuławska, Zofia, 1994, Milanówek 1899-1939 (Dokumenty i wspomnienia), Milanówek: OTM.; Sierosławski, Stanisław, 1913, Nasz rok. Kalendarz na rok 1913, Warszawa: Towarzystwo Akcyjne „Świat”. [Accessed 9 December 2018]. Available from: http://rcin.org.pl. 